Article

\title{
Biodistribution and Anticancer Characteristics of Les-3833, A Novel 4-thiazolidinone-Based Lead Compound
}

\author{
Lesya Kobylinska ${ }^{1, *(\mathbb{D}}$, Andrii Lozynskii ${ }^{2}$, Roman Lesyk ${ }^{2,3, * \mathbb{C}}$, Rostyslav Stoika ${ }^{4}$ \\ and Sandor G. Vari ${ }^{5}($ ) \\ 1 Department of Biochemistry, Danylo Halytsky Lviv National Medical University, Pekarska Street 69a, \\ 79010 Lviv, Ukraine \\ 2 Department of Pharmaceutical, Organic and Bioorganic Chemistry, Danylo Halytsky Lviv National Medical \\ University, Pekarska Street 69a, 79010 Lviv, Ukraine; lozynskyiandrii@gmail.com \\ 3 Department of Public Health, Dietetics and Lifestyle Disorders, Faculty of Medicine, University of Information \\ Technology and Management in Rzeszow, Sucharskiego 2, 35-225 Rzeszow, Poland \\ 4 Department of Regulation of Cell Proliferation and Apoptosis, Institute of Cell Biology, National Academy \\ of Sciences of Ukraine, Drahomanov Street 14/16, 79005 Lviv, Ukraine; stoika.rostyslav@gmail.com \\ 5 International Research and Innovation in Medicine Program, Cedars-Sinai Medical Center, 6500 Wilshire Blvd., \\ 21st floor, Suite 2102, Los Angeles, CA 90048-5502, USA; Sandor.Vari@cshs.org \\ * Correspondence: lesya8@gmail.com (L.K.); dr_r_lesyk@org.lviv.net (R.L.); Tel.: +38-(032)-275-76-02 (L.K.); \\ +38-(032)-275-59-66 (R.L.)
}

Received: 1 March 2020; Accepted: 25 March 2020; Published: 30 March 2020

check for updates

\begin{abstract}
Recently, we identified the promising anticancer potential of the synthetic 4-thiazolidinone-based anticancer lead compound Les-3833 which demonstrated tumor-suppressing action in vitro and in vivo. Based on the results of previous studies, the aim of this research was to investigate the cytotoxicity in vitro and the biodistribution in laboratory mice to support the biotherapeutic drug development of Les-3833. Les-3833 $(2.5 \mathrm{mg} / \mathrm{kg})$ was intravenously injected into male Balb/c mice. Measurements were performed at $5 \mathrm{~min}, 15 \mathrm{~min}, 1 \mathrm{~h}, 4 \mathrm{~h}$, and $24 \mathrm{~h}$ time points in blood plasma, brain, liver, and kidney using high-performance liquid chromatography/tandem mass spectrometry. After the administration of Les-3833, the maximum level of this compound was observed in plasma at $2.08 \mathrm{~min}$. In the brain, the mean maximum concentration of Les-3833 was $7.17 \mathrm{ng} / \mathrm{mL}$ at $5 \mathrm{~min}$, while after $15 \mathrm{~min}$, it was not found. In the liver, at $5 \mathrm{~min}$, the maximum concentration was $1190 \mathrm{ng} / \mathrm{g}$. At $15 \mathrm{~min}$, concentration of Les-3833 in the liver decreased by 14.3\%; at $6 \mathrm{~h}$ by $22.8 \%$; and after $24 \mathrm{~h}$ by $64.7 \%$. Its maximum concentration in kidney was $404 \mathrm{ng} / \mathrm{g}$ within 5-15 $\mathrm{min}$, at $1 \mathrm{~h}$ it decreased by $36.1 \%$, and after $24 \mathrm{~h}$ by $49.3 \%$. Thus, Les-3833 was rapidly taken up by different organs from the bloodstream, partially metabolized in the liver, and excreted mainly through the kidneys, while in the brain, a very low concentration could be observed for only a short period of time.
\end{abstract}

Keywords: BALB/C mice; cytotoxicity; biodistribution; 4-thiazolidinone derivative

\section{Introduction}

Development of any new drug involves an assessment of the benefit-risk balance between the effective therapeutic dose levels and the potential side effects and toxicity levels that may diminish or nullify the curative effects of new substances [1,2]. Therefore, the importance of the early evaluation of toxic properties of drug candidates cannot be underestimated [3]. 
Biodistribution studies support the early development of a biotherapeutic drug and track where the drug travels in experimental animals or human subjects. Quantitative measurements can be made in the organs of interest by using high-performance liquid chromatography [4]. In biodistribution studies, new compounds are injected intravenously into a group of animals, typically rodents such as mice or rats at intervals of $1,2,4$, and $24 \mathrm{~h}$, and then $\mathrm{C}_{\max }$, AUC, and $\mathrm{t}_{1 / 2}$ can be studied [5]. The results give a dynamic view of how the compound moves through the body of the animal.

Pharmacokinetics describes how the body affects the specific chemicals in a drug compound that have been administered by an oral, intravenous (IV) or other route and how these chemicals are affected by the mechanisms of absorption, distribution, metabolism, and elimination; these mechanisms can have a dramatic impact on the biosafety and efficacy of the investigated compounds [6]. Pharmacokinetic studies during the preclinical stage support the improvement of drug candidates and provide information for evaluating their possible clinical applications $[7,8]$. The information obtained is also useful for choosing doses in efficacy studies, providing preliminary identification for drug-specific toxicity in the target organs, and, in some cases, revealing delayed toxicity [3].

During a search for potential biologically active molecules as drug candidates, novel 4-thiazolidinone derivatives were synthesized by our team and their anticancer potential was evaluated at the National Cancer Institute (Bethesda, Maryland, USA) towards 60 human cancer cell lines and then studied in more detail through targeting of selected human tumor cells in culture [9] and in rats [10] and mice bearing experimental tumors [11]. Among the various synthesized 4-thiazolidinones, anticancer, antioxidant, anti-inflammatory, anti-microbial, and anti-trypanosomal agents have been identified [12]. It is known that the combination of different bioactive fragments with complementary pharmacophoric functions is often a precondition for creating ligand-target binding and potential selectivity for bio-targets [13].

Among the non-condensed 4-thiazolidinone derivatives, considerable attention has been drawn to the pyrazoline-thiazolidinone-isatin conjugates due to the fact of their significant anticancer activity. It was found that the antitumor mechanisms of these derivatives can be associated with their affinity to c-Jun NH(2)-terminal kinase (JNK) stimulating phosphatase-1 (JSP-1), cyclin-dependent kinases (CDKs), tyrosine kinase, tumor necrosis factor alpha (TNF $\alpha)$, vascular endothelial growth factors, and P-glycoprotein [14-16]. We have shown that the 4-thiazolidinone derivative Les-3833 induced the accumulation of tumor cells in the G1-G0 phase, increased the ratio of Annexin V-positive cells, and increased the amount of pro-apoptotic cleaved caspase-3 in treated cells [17].

Recently, we designed and synthesized a series of non-condensed heterocyclic compounds containing 4-thiazolidinone, 2,3-dihydro- $1 H$-indol-2-one, and pharmacologically attractive pyrazole or pyrazoline moieties [18]. Among a series of mentioned pyrazoline-thiazolidinone-isatin conjugates, the Les-3833 was found to be the most active compound in accordance with the protocol of the Drug Evaluation Branch, National Cancer Institute (www.dtp.nci.nih.gov), with mean GI (growth $_{50}$ inhibition of 50\%) and TGI (total growth inhibition) levels of 0.071 and $0.76 \mu \mathrm{M}$, respectively [18]. The structure of Les-3833 is shown in Figure 1.

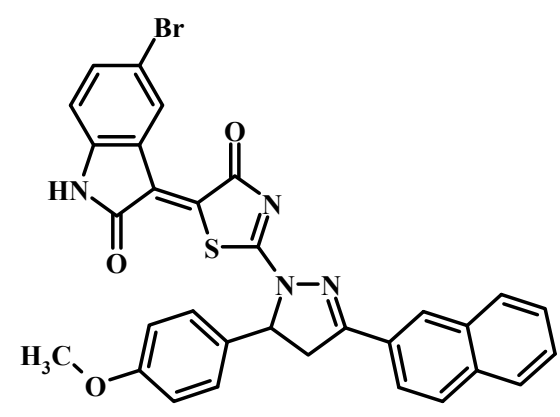

Figure 1. Structure of the investigated Les-3833 compound. 
For the anticancer lead compound Les-3833 that contains 2,3-dihydro- $1 H$-indol-2-one 4-thiazolidinone, the objectives of the present work were to determine its (1) cytotoxicity in vitro in human myeloid leukemia HL-60 and human colon carcinoma HCT116 cells and (2) its biodistribution in the blood plasma, brain, kidney, and liver of laboratory mice. The study findings might provide useful information for further drug design based on this heterocyclic compound.

\section{Materials and Methods}

\subsection{Drug}

The Les-3833 is 5-bromo-3-\{2-[5-(4-methoxyphenyl)-3-naphthalen-2-yl-4,5-dihydropyrazol-1yl]-4-oxo-4,5-dihydro-1,3-thiazol-5-ylidene\}-2,3-dihydro- $1 H$-indol-2-one, with $\mathrm{Mr}=609.51 \mathrm{~g} / \mathrm{mole}$. Les-3833 was supplied as a dry powder and dissolved in Captisol (Ligand Pharmaceuticals, Inc., San Diego, CA, USA; 10\% of final Captisol concentration in the formulation). The final Les-3833 concentration was $0.5 \mathrm{mg} / \mathrm{mL}$. The batches of working formulations were prepared $1 \mathrm{~h}$ prior to the in vivo study.

\subsection{Cytotoxicity In Vitro}

Human myeloid leukemia HL-60 and human colon carcinoma HCT116 cells were obtained from the Institute of Cancer Research at Vienna Medical University (Vienna, Austria). Human breast adenocarcinoma MCF-7, human T-cell leukemia Jurkat cells, rat glioma C6 cells, and human glioma U251 cells were obtained from the Collection of the Institute of Experimental Pathology, Oncology and Radiobiology named by R.E. Kavetsky, National Academy of Science of Ukraine (Kyiv, Ukraine). Cells were grown in RPMI-1640 culture medium (Thermo Fisher Scientific, Vienna, Austria) or Dulbecco's modified Eagle's medium (DMEM, Sigma-Aldrich, St. Louis, MO, USA) supplemented with $10 \%$ fetal bovine serum (Biowest, Nuaillé, France) at the standard conditions.

The cytotoxicity was measured using the trypan blue exclusion test. Cells were plated at 50,000 cells/well (substrate-dependent cells) or 500,000 cells/well (suspension cells) in $1 \mathrm{~mL}$ in 24 well plates and allowed to incubate overnight. The cell number was counted in a hemocytometric Neubauer chamber after staining with trypan blue dye (DV-T10282, Invitrogen, Life Technologies Corporation, Camarillo, CA, USA) at $0.04 \%$ final concentration. The percentage of live cells related to control was calculated as the cell number experiment/cell number control $\times 100 \%$.

\subsection{In Vivo Biodistribution Study}

Study design, animal selection, handling, and treatment were all in accordance with the pharmacokinetic study protocols and Institutional Animal Care and Use Guidelines of Danylo Halytsky Lviv National Medical University, Lviv, Ukraine. The Ethical Committee of Bienta, Biological Services Department Bienta/Enamine Ltd, Kiev, Ukraine ratified the Institutional Animal Care and Use Approval \#10, dated on 07 November 2018.

Fifty-five male Balb/c mice (9-10 weeks old, body weight $26.3 \pm 2.1 \mathrm{~g}$ ) were used in this study. The animals were obtained from the breeding facility of the Institute of Pharmacology and Toxicology, Academy of Medical Science of Ukraine, Kiev, and acclimatized for 7 days. Intravenous (IV) injection and a five time point setup ( $5 \mathrm{~min}, 15 \mathrm{~min}, 1 \mathrm{~h}, 4 \mathrm{~h}, 24 \mathrm{~h}$ ) were used in this study. Each time point treatment group included 5 mice. The five control animals were treated with 20\%:80\% Captisol-physiological saline formulation at equal volume. The animals were weighed in the morning, $1 \mathrm{~h}$ before the dosing.

The dosing was done according to the treatment schedule outlined in Table 1. Prior to drawing blood, mice were given IV injections of 2,2,2-tribromoethanol at the dose of $150 \mathrm{mg} / \mathrm{kg} ; 0.5 \mathrm{~mL}$ of whole blood was taken from the orbital sinus and placed in microtubes (MicroTube, lot\# 171205; Sarstedt, Nümbrecht, Germany); the interiors of the microtubes were coated with dipotassium ethylenediaminetetraacetic acid $\left(\mathrm{K}_{2}\right.$ EDTA). After that, the animals were sacrificed by cervical dislocation. The microtubes were placed on ice immediately after blood drawing. For the following 20-30 min, 
the microtubes were spun in a cooled centrifuge (AccuSpin Micro 17R, Fisher Scientific, Waltham, MA, USA) at $3000 \mathrm{rpm}$ for $10 \mathrm{~min}$. Blood plasma was transferred to $1.5 \mathrm{~mL}$ Eppendorf vials, then frozen and kept at $-20{ }^{\circ} \mathrm{C}$.

The kidney, brain, and liver specimens were collected at each of the five time points ( $5 \mathrm{~min}, 15 \mathrm{~min}$, $1 \mathrm{~h}, 4 \mathrm{~h}, 24 \mathrm{~h}$ ), weighed using analytical balances (Mettler Toledo PM400, Greifensee, Switzerland) $0.001 \mathrm{~g}$, and kept at $-70{ }^{\circ} \mathrm{C}$.

Table 1. Study design and treatment schedule.

\begin{tabular}{|c|c|c|c|c|c|c|}
\hline $\begin{array}{l}\text { Number of } \\
\text { Mice (Male) }\end{array}$ & Compound & Formulation & $\begin{array}{l}\text { Delivery } \\
\text { Route }\end{array}$ & $\begin{array}{c}\text { Target Dose } \\
\text { Level } \\
(\mathrm{mg} / \mathrm{kg})\end{array}$ & $\begin{array}{l}\text { Target Dose } \\
\text { Concentration } \\
(\mathrm{mg} / \mathrm{mL})\end{array}$ & $\begin{array}{l}\text { Target Dose } \\
\text { Volume } \\
\text { (ml/kg) }\end{array}$ \\
\hline 50 & Les-3833 & $\begin{array}{c}20 \%: 80 \% \\
\text { Captisol: } \\
\text { physiological saline } \\
\text { solution }\end{array}$ & IV & 2.5 & 0.5 & 5 \\
\hline 5 & Vehicle & $\begin{array}{c}20 \%: 80 \% \\
\text { Captisol: } \\
\text { physiological } \\
\text { saline solution }\end{array}$ & IV & 0 & 0 & 5 \\
\hline
\end{tabular}

The concentrations of Les-3833 in blood plasma, kidney, brain, and liver were determined by the high-performance liquid chromatography/tandem mass spectrometry (HPLC-MS/MS) Shimadzu Prominence system (Shimadzu Corp., Kyoto, Japan). After centrifugation (described below), aliquots from each supernatant ( $1 \mu \mathrm{L}$ : plasma, liver or kidney; $3 \mu \mathrm{L}$ : brain) were injected into the HPLC-MS/MS system. A solution of dactinomycin $(400 \mathrm{ng} / \mathrm{mL}$ in acetonitrile-methanol mixture 1:1, v/v) was used as the internal standard (IS) for the quantification of Les-3833 in plasma samples. The mass spectrometric analysis was performed using an API 3000 (triple-quadrupole) instrument from AB Sciex (Concord, Ontario, Canada) with an electrospray interface. The data acquisition and system control were performed using Analyst 1.5.2 software from AB Sciex. The concentrations of Les-3833 that were below the lower limit of quantitation (LLOQ $=50 \mathrm{ng} / \mathrm{g}$ for liver and kidney) were designated as zero.

\subsubsection{Calibration Standards for Quantification of Les-3833 in Blood Plasma Samples}

The compound Les-3833 was dissolved in dimethyl sulfoxide (DMSO), and a resulting solution with a concentration of $1 \mathrm{mg} / \mathrm{mL}$ was used for preparation of calibration standards (stock solution). A series of 12 calibration standards was prepared by sequential dilution of the stock compound solution with blank mouse plasma to a final concentration of 20,000, 10,000, 5000, 2500, 1000, 500, 250, 100, 50, 20, 10 , and $5 \mathrm{ng} / \mathrm{mL}$. Standard plasma samples $(50 \mu \mathrm{L})$ were mixed with $200 \mu \mathrm{L}$ of the IS. After mixing by pipetting and centrifugation for $4 \mathrm{~min}$ at $6000 \mathrm{rpm}, 1 \mu \mathrm{L}$ of each supernatant was injected into the LC-MS/MS system.

\subsubsection{Calibration Standards for Quantification of Les-3833 in Brain Tissue}

The stock solution of Les-3833 (described above) was consecutively diluted with IS400(80) to obtain a series of 13 calibration solutions with final concentrations of 20,000, 5000, 2500, 1000, 500, 250, $100,50,25,10,5,2$, and $1 \mathrm{ng} / \mathrm{mL}$. A calibration curve was constructed using blank mouse brain samples. To obtain calibration standards, blank brain samples (average weight $100 \pm 1 \mathrm{mg}$ ) were homogenized in $500 \mu \mathrm{L}$ of corresponding calibration solution using zirconium oxide beads $(150 \pm 5 \mathrm{mg})$ in The Bullet Blenderßhomogenizer for $1 \mathrm{~min}$ at speed 8 . After this, the samples were centrifuged for $1 \mathrm{~min}$ at $14,000 \mathrm{rpm}$, and $3 \mu \mathrm{L}$ of each supernatant was injected into the LC-MS/MS system.

\subsubsection{Calibration Standards for Quantification of Les-3833 in Liver and Kidney Tissues}

The stock solution of Les-3833 was consecutively diluted with IS to obtain a series of 13 calibration solutions with final concentrations of 20,000,5000, 2500, 1000, 500, 250, 100, 50, 25, 
10, 5, 2, and $1 \mathrm{ng} / \mathrm{mL}$. A calibration curve was constructed using blank mouse liver or kidney samples. To obtain calibration standards, blank liver or kidney samples (average weight $100 \pm 1 \mathrm{mg}$ ) were homogenized in $500 \mu \mathrm{L}$ of corresponding calibration solution using stainless-steel beads (150 $\pm 5 \mathrm{mg})$ in The Bullet Blenderßhomogenizer for $1 \mathrm{~min}$ at speed 8. After this, the samples were centrifuged for $4 \mathrm{~min}$ at 14,000 rpm, and $1 \mu \mathrm{L}$ of each supernatant was injected into the LC-MS/MS system.

The definitions for calculation of distribution volume (V) and the clearance (CL) definitions are largely dependent on a pharmacokinetic model:

$$
\begin{gathered}
C L=\text { drug amount eliminated per unit of time/drug concentration in plasma } \\
\qquad \mathrm{V}=\text { drug amount in the body/drug concentration in plasma }
\end{gathered}
$$

The CL is not time dependent, and it may be shown that $C L=D / A U C$. Volume cannot be time independent because of drug distribution in tissues outside the plasma; but under some general assumptions, it may be shown that the ratio of CL approaches a limit value given by $V_{\text {area }}=D / \lambda \times$ AUC, where D is the drug amount that enters into the systemic circulation (after IV an intravenous administration, $\mathrm{D}$ is the dose), and $\lambda$ is the lowest exponent used to get the terminal half-life. $V_{\text {area }}$ has been used to characterize the drug distribution in the total body, while CL is a measure of the efficiency of the drug elimination process.

Selected key distribution parameters of Les-3833 in blood plasma, brain, liver, and kidney clearance $(\mathrm{CL})$ and distribution $\left(\mathrm{V}_{\text {area }}\right)$ were determined using the Phoenix WinNonlin software program (Certara, St. Louis, USA). For practical reasons, sampling in the present study was restricted to $24 \mathrm{~h}$ post-dose.

\subsection{Statistical Analysis}

Pharmacokinetic parameters were calculated by means of standard non-compartmental analysis using a commercially available computer program (Kinetica 3.0, Innaphase Corp., Philadelphia, PA, USA). Maximum plasma concentration $\left(C_{\max }\right)$, time to maximum plasma concentration $\left(T_{\max }\right)$, and area under the concentration-time curve from 0 to the last measured concentration $\left(\mathrm{AUC}_{0-24}\right)$ were calculated from non-fitted data. For the AUC calculation, the trapezoidal rule was employed. For an accurate description of the pharmacokinetic profile of drugs with long half-lives, the US Food and Drug Administration recommends a sampling period covering 3-5 half-lives of the investigated drug [19]. Statistical analysis was performed using a commercially available program (IBM SPSS Statistics 22; IBM Corp., Armonk, NY, USA). A p-value of 0.05 was considered as the threshold for statistical significance. All values are shown as the mean \pm standard deviation unless otherwise stated.

\section{Results}

\subsection{Evaluation of Cytotoxic Effect of Les-3833 on Different Cell Lines In Vitro}

Before initiating a biodistribution study of Les-3833 in vivo, we analyzed the results of our former investigations for the cytotoxic effect of this potential anticancer agent in vitro. The biological activity of this 4-thiazolidinone derivative was determined by its action in vitro against six different cell lines. To determine the cytotoxic activity of these compounds and the $\mathrm{LC}_{50}$ value, a viability method based on staining of trypan blue cells was used. The results presented in Table 2 demonstrate that the average cytotoxicity index of Les-3833 is in the range of $0.83-4.75 \mu \mathrm{m}$, depending on the cell line. Human and rat (C6) glioma cells were the most sensitive to the toxic action of Les-3833. It should be noted that the $\mathrm{LC}_{50}$ values for Les-3833 targeting these glioma cells, $0.84 \mu \mathrm{g} / \mathrm{mL}$ for U251 and $0.89 \mu \mathrm{g} / \mathrm{mL}$ for C6 lines (Table 2), were comparable to those calculated for the effect of doxorubicin, $0.90 \mu \mathrm{g} / \mathrm{mL}$ and $0.84 \mu \mathrm{g} / \mathrm{mL}$, respectively [20]. 


\subsection{Biodistribution Study of Les-3833 In Vivo}

The next step of our study was to perform the in vivo investigation of the acute toxicity of Les-3833. The initial dose of Les-3833 was $10 \mathrm{mg} / \mathrm{kg}$, but one animal died immediately after the first injection. Thereafter, the dose was decreased 4 fold to $2.5 \mathrm{mg} / \mathrm{kg}$. Figure 2 shows that the blank mouse plasma and brain and liver tissues did not interfere with Les-3833 and the IS.

Table 2. $\mathrm{IC}_{50}$ values for Les-3833 in different cancer cell lines.

\begin{tabular}{ccc}
\hline Cell Lines & Les-3833 $\boldsymbol{\mu g} / \mathbf{m L}$ & Doxorubicin $\boldsymbol{\mu g} / \mathbf{m L}$ \\
\hline human acute promyelocytic leukemia HL-60 & $2.04 \pm 0.21$ & $0.09 \pm 0.01$ \\
breast adenocarcinoma cells MCF-7 & $4.75 \pm 0.24$ & $1.38 \pm 0.12$ \\
human glioma U251 cells & $0.84 \pm 0.09$ & $0.90 \pm 0.11$ \\
rat glioma C6 cells & $0.89 \pm 0.12$ & $0.84 \pm 0.08$ \\
human melanoma WM793 cells & $0.22 \pm 0.03$ & $0.24 \pm 0.05$ \\
human melanoma SK-MEL-28 cells & $0.30 \pm 0.04$ & $0.35 \pm 0.06$ \\
human lung carcinoma A549 cells & $2.50 \pm 0.19$ & $0.80 \pm 0.05$ \\
human colorectal carcinoma HCT-116 & $3.40 \pm 0.32$ & $1.10 \pm 0.09$ \\
human embryonic kidney HEK293 cells & $>5$ & $3.20 \pm 0.42$
\end{tabular}
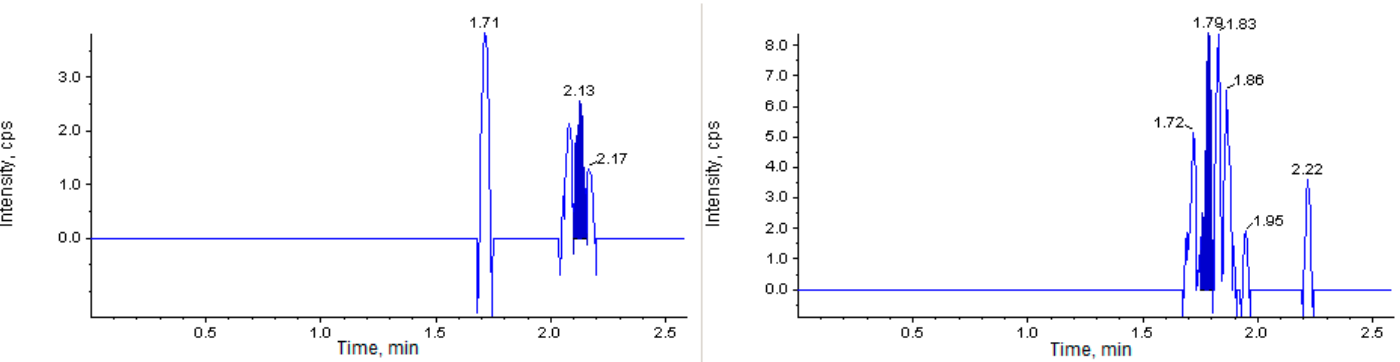

(A)
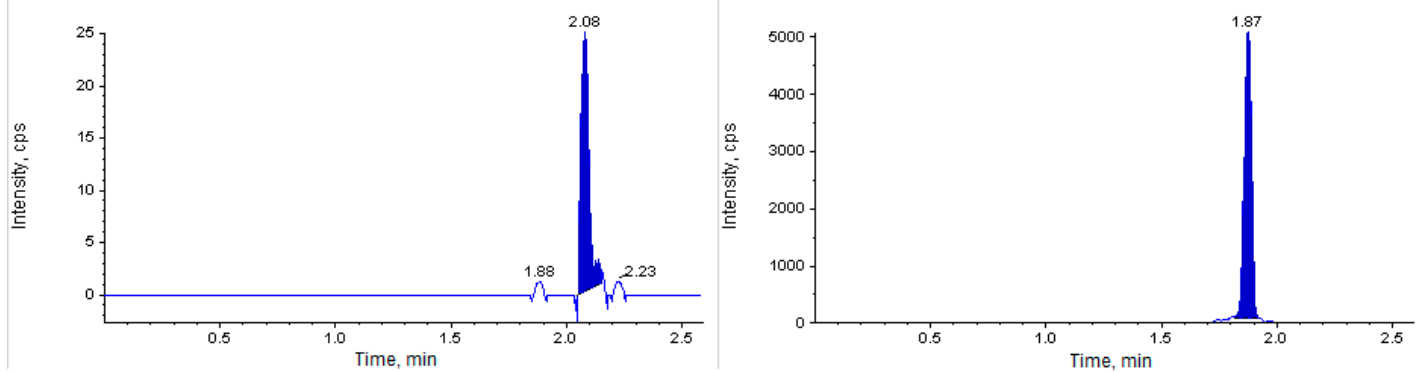

(B)
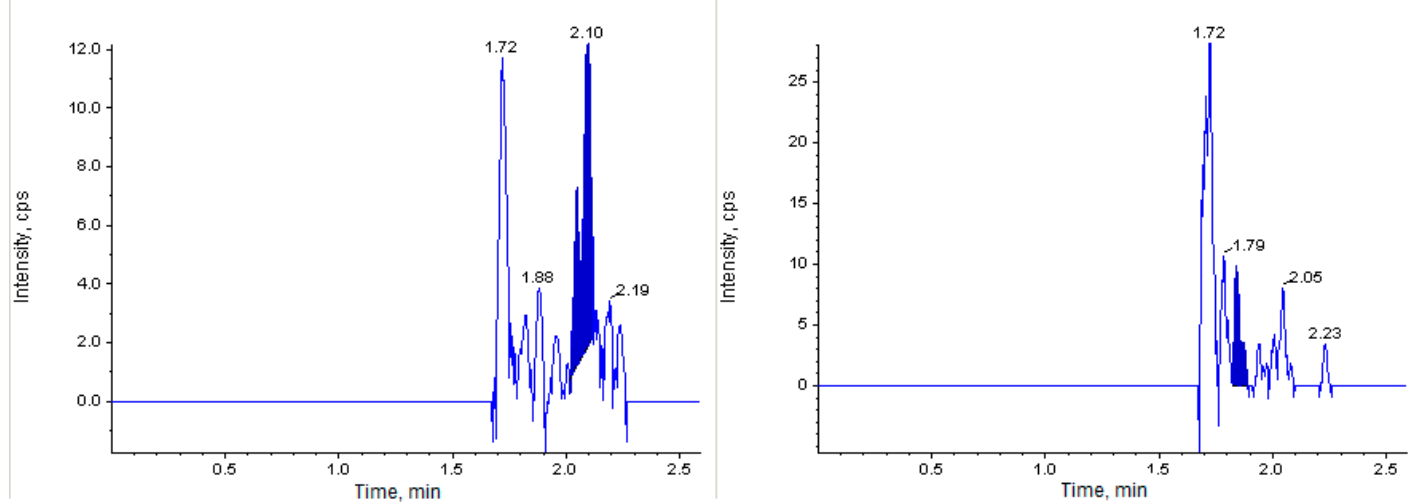

(C)

Figure 2. Cont. 

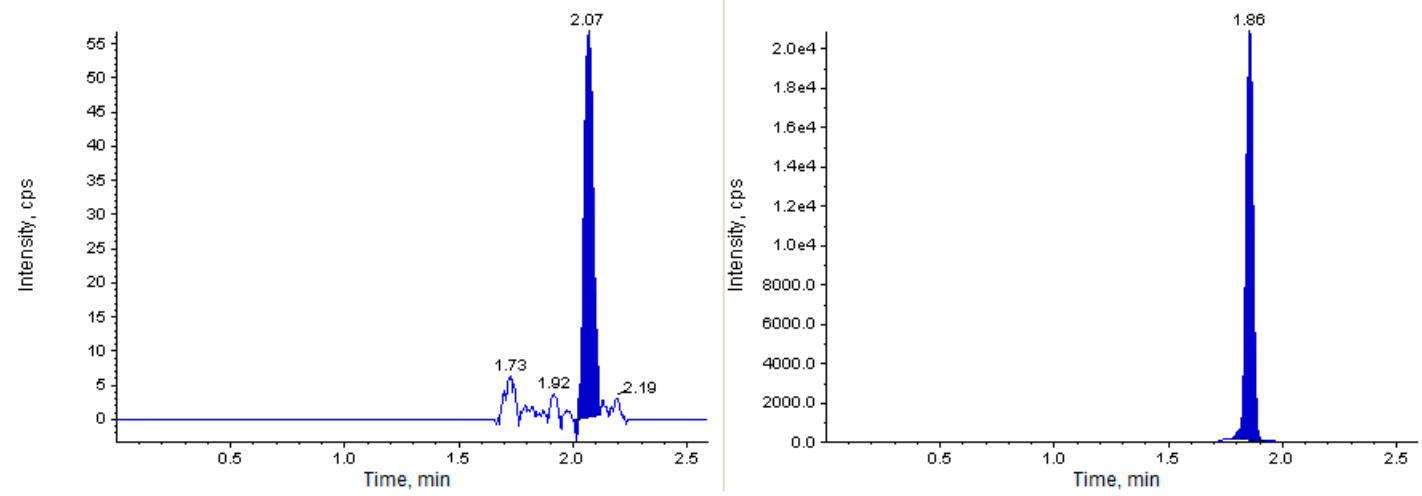

(D)
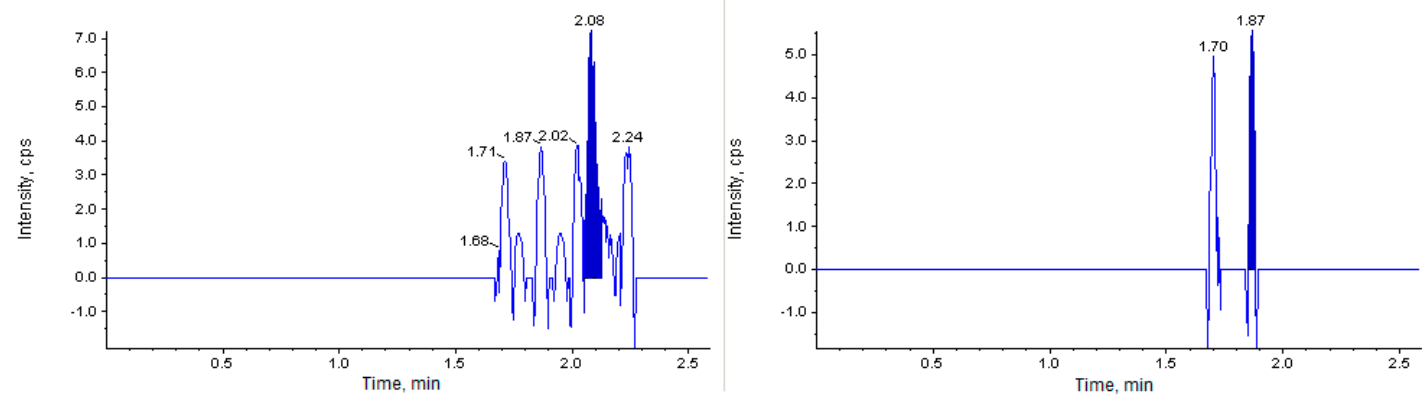

(E)
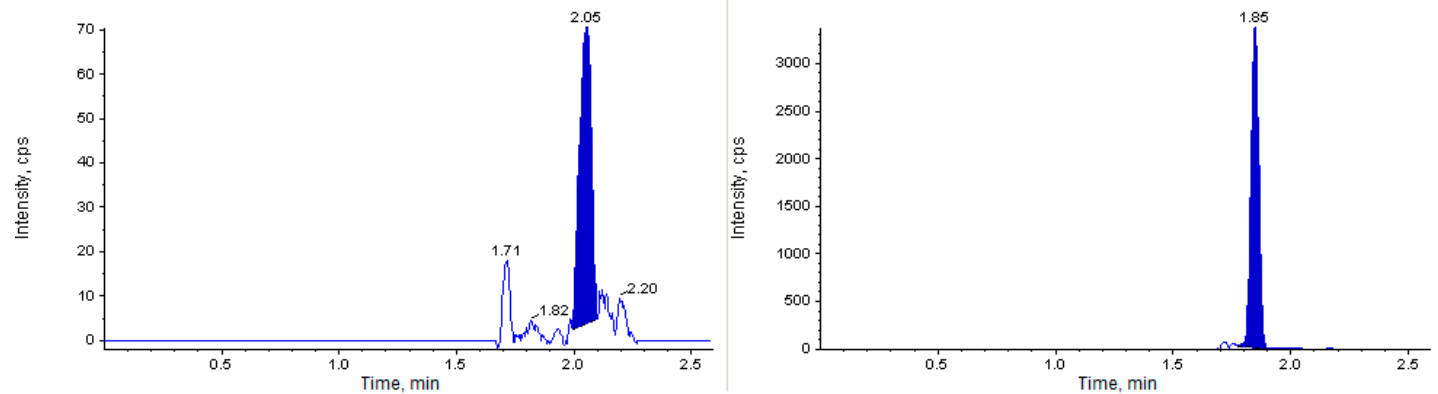

(F)

Figure 2. Chromatographic plots from the in vivo investigation of the acute toxicity of Les-3833 in male Balb/c mice. (A) blank plasma sample, (B) blank plasma spiked with Les-3833 (5 ng/mL, left panel) and internal standard (IS, dactinomycin, right panel), (C) blank brain sample, (D) blank brain sample spiked with Les-3833 (10 ng/g, left panel) and IS (right panel), (E) blank liver sample, and (F) blank liver sample spiked with Les-3833 (50 ng/g, left panel) and IS (right panel).

After IV administration, the Les-3833 concentration in blood plasma reached its maximum at 1.88 to $2.23 \mathrm{~min}$. The peak concentration was observed at $2.08 \mathrm{~min}$ after the IV injection. The maximum plasma concentration of Les-3833 was $5.55 \pm 0.25 \mathrm{ng} / \mathrm{mL}$, and the half-life of its elimination was $15 \mathrm{~min}$ (Figure 3, Table 3).

In the brain, the maximum concentration of Les-3833 was observed at $5 \mathrm{~min}$, but was only $7.17 \mathrm{ng} / \mathrm{g}$, and the half-life of its elimination was 15 min (Figure 3, Table 3). After 60 min, Les-3833 could not be detected in brain tissue (Figure 3).

In the liver, at $5 \mathrm{~min}$, the maximum concentration was $1246 \mathrm{ng} / \mathrm{g}$ (Table 3). At $15 \mathrm{~min}$, it had decreased by $14.3 \%$, at $6 \mathrm{~h}$ by $22.8 \%$, and after $24 \mathrm{~h}$ by $64.7 \%$ (Figure 3 ).

In the kidney, the maximum concentration was $404 \mathrm{ng} / \mathrm{g}$ within 5-15 min (Table 3). At $1 \mathrm{~h}$, the concentration decreased by $36.1 \%$ and after $24 \mathrm{~h}$ decreased by $49.3 \%$ (Figure 3 ). 


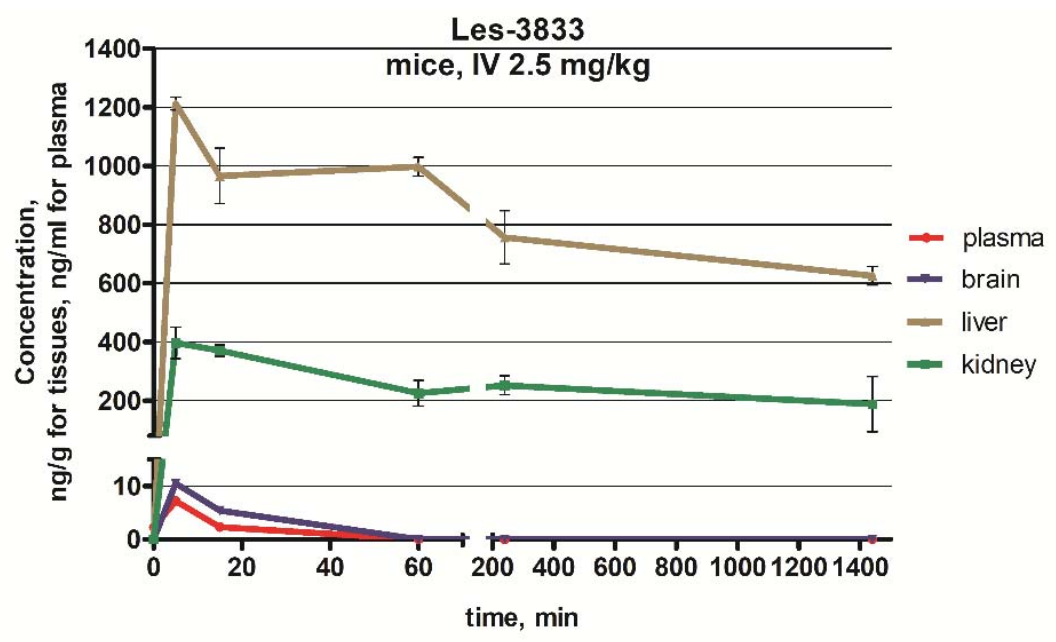

Figure 3. Concentration-time curves for Les-3833 following dosing during $24 \mathrm{~h}$ in the plasma, brain, liver, and kidney of male Balb/c mice. Since the concentrations of Les-3833 were very low for plasma (approximately $5 \mathrm{ng} / \mathrm{mL}$ ) and brain $(<10 \mathrm{ng} / \mathrm{g})$, the $X$-axis and $Y$-axis each consist of two segments.

Mean values of $C_{\max }$ after IV dosing reached approximately 1190 and $404 \mathrm{ng} / \mathrm{g}$ in liver and kidney, respectively (Table 3). Overall bioavailability in the brain was slightly poorer, with a mean $C_{\max }$ of 7.17 after IV exposure.

Table 3. Pharmacokinetic parameters for Les-3833 in male Balb/c mice.

\begin{tabular}{|c|c|c|c|c|c|c|c|c|}
\hline Sample & $\begin{array}{l}\text { Administration } \\
\text { Route }\end{array}$ & $\begin{array}{l}\text { Dose, } \\
\mathrm{mg} / \mathrm{kg}\end{array}$ & $\begin{array}{l}\mathrm{T}_{\max } \\
\min \end{array}$ & $\mathrm{C}_{\max }, \mathrm{ng} / \mathrm{mL}, \mathrm{ng} / \mathrm{g}$ & $\begin{array}{c}\mathrm{AUC}_{0 \rightarrow \mathrm{t} \text { min }} \\
\text { (AUClast) ng } \times \\
\mathrm{min} / \mathrm{mL}\end{array}$ & $\begin{array}{c}\text { AUC }_{0 \rightarrow \infty} \\
(\mathrm{AUCINF} \text { obs) } \\
\mathrm{ng} \times \mathrm{min} / \mathrm{mL}\end{array}$ & $\begin{array}{c}\mathrm{T}_{1 / 2} \\
\left(\mathrm{HL}_{-} \lambda\right. \\
-\mathrm{z}), \mathrm{min}\end{array}$ & $\begin{array}{c}\mathrm{K}_{\mathrm{el}} \\
\left(\lambda_{-} \mathrm{z}\right), \min ^{-1}\end{array}$ \\
\hline Plasma & IV & 2.5 & 2.08 & $5.55 \pm 0.25$ & 119.9 & 119.9 & 15 & $1.10 \times 10^{-1}$ \\
\hline Liver & IV & 2.5 & 5.00 & $1246 \pm 65$ & $1,190,000$ & $4,070,000$ & 2880 & $2.40 \times 10^{-4}$ \\
\hline Kidney & IV & 2.5 & 15.0 & $404 \pm 39$ & 370,000 & $1,280,000$ & 3090 & $2.24 \times 10^{-4}$ \\
\hline
\end{tabular}

The $\mathrm{AUC}_{0-24}$ mean values after IV dosing reached 1,190,000 and 370,000 in the liver and the kidney, respectively (Table 3). The $\mathrm{AUC}_{0-24}$ mean values determined for the full elimination of Les-3833 by the liver and the kidney. The $\mathrm{AUC}_{0-24}$ of Les-3833 in blood plasma was significantly lower than that in the liver and kidney (Table 3).

The differences in $\mathrm{AUC}_{0-24}$ between the liver, kidney, and brain was significant (Table 3). After IV injection, peak concentrations in liver and brain were reached more rapidly than in kidney $\left(\mathrm{T}_{\max }=5 \mathrm{~min}\right.$ for liver, brain versus $15 \mathrm{~min}$ for kidney). The Les-3833 concentrations in the liver were higher than in the brain and kidney, but then showed an elimination of almost two times in $24 \mathrm{~h}$ from $1246 \mathrm{ng} / \mathrm{g}$ to $692 \mathrm{ng} / \mathrm{g}$ (Figure 3). In kidney, the $\mathrm{C}_{\max }$ of Les-3833 was three times lower than in the liver, but the elimination half-life was longer, and half of the drug was eliminated in $24 \mathrm{~h}$ (Table 3 ).

\subsection{Biodistribution Parameters for Les-3833 in Male Balb/c Mice}

The results presented in Table 4 show that the distribution of Les-3833 takes place in the liver and kidney, since the terminal half-life of this compound in these organs was $48 \mathrm{~h}$ and $51.5 \mathrm{~h}$, respectively (Table 3, $2880 \mathrm{~min}$ and $3090 \mathrm{~min}$, respectively). The $\mathrm{V}_{\text {area }}$ in these organs was the smallest, suggesting fast drug distribution in the total body and its relatively slow elimination. In contrast, the extremely low half-life of this compound in blood plasma and brain (15 min) suggests that it is not retained in these tissues. Thus, the elimination of Les-3833 from the organism was carried out through the liver and kidney. 
Table 4. The clearance and distribution $\left(\mathrm{V}_{\text {area }}\right)$ of Les-3833 in male Balb/c mice.

\begin{tabular}{ccccc}
\hline & Plasma & Brain & Liver & Kidney \\
\hline Clearance & $2.09 \times 10^{-2}$ & $13.97 \times 10^{-2}$ & $2.10 \times 10^{-6}$ & $6.8 \times 10^{-6}$ \\
V $_{\text {area }}$ & $1.90 \times 10^{-1}$ & $4.45 \times 10^{-1}$ & $8.75 \times 10^{-3}$ & $3.02 \times 10^{-2}$ \\
\hline
\end{tabular}

\section{Discussion}

We studied the biodistribution of a novel 4-thiazolidinone derivative with anticancer potential approved at the National Cancer Institute (NCI, USA) under the Developmental Therapeutics Program. The results of that study had shown that the pyrazoline-substituted 4-thiazolidonone derivatives possessed anticancer action, and the pyrazoline-thiazolidinone-indoline derivative, Les-3833, was the most promising candidate for further pre-clinical study [18]. Les-3833 was highly active towards the non-small-cell lung cancer cell line HOP-92 $\left(\mathrm{GI}_{50}<0.01 \mu \mathrm{M}\right)$, colon cancer line HCT-116 $\left(\mathrm{GI}_{50}=0.018 \mu \mathrm{M}\right)$, CNS cancer cell line SNB-75 $\left(\mathrm{GI}_{50}=0.0159 \mu \mathrm{M}\right)$, ovarian cancer cell line OVCAR-3 $\left(\mathrm{GI}_{50}=0.0216 \mu \mathrm{M}\right)$, and renal cancer cell line RXF $393\left(\mathrm{GI}_{50}=0.0197 \mu \mathrm{M}\right)[18,21]$. Les-3833 also demonstrated lower general toxicity in vivo compared with that of doxorubicin $[10,21-24]$.

The drug concentration in blood plasma determines the magnitude of the pharmacological responses. The biodistribution study of Les-3833 in mice supports the pre-clinical toxicology investigation, because the drug levels in plasma or tissues are often predictive for toxicity and significant for effective therapeutic application. Biodistribution is an important approach for verifying the measurable AUC and the $\mathrm{C}_{\max }$ of the drug in blood plasma of treated animals. These parameters can be used to predict the exposure of the investigated drug in the human body. Biodistribution can also show differences among various treatment groups, days of treatment, and other factors as well as estimate the variability among animals and identify cases with abnormal levels of the drug [8,25].

The AUC might be used as an index of the drug exposure of particular tissues, if referred to the drug levels in tissues. The area under the plasma drug concentration curves is a parameter that is closely dependent on the drug amount that enters into the systemic circulation and has to be eliminated (termed as clearance). Therefore, AUC can be used to measure the drug amount absorbed by the body and estimate the efficiency of the physiological processes that characterize the drug elimination.

Doxorubicin is considered the "gold standard" in cancer chemotherapy. The results of its pharmacokinetics in rats [26] demonstrated that after IV administration, the $C_{\max }(1.7 \mu \mathrm{g} / \mathrm{mL})$ in plasma was achieved immediately after injection, and by $1 \mathrm{~h}$, the concentration was reduced to $0.3 \mu \mathrm{g} / \mathrm{mL}$. In our experiments, we treated mice with free Les-3833 and found that it was cleared very rapidly from blood plasma of treated mice. Its mean peak concentration $(5.55 \mathrm{ng} / \mathrm{mL})$ was achieved at $2.08 \mathrm{~min}$ after administration. After that, its concentration in blood plasma gradually decreased below the limit of quantitation.

When doxorubicin clearance was monitored in liver and kidney of rats, a decrease from $26.4 \pm 0.2 \mu \mathrm{g} / \mathrm{g}(30 \mathrm{~min})$ to $4.1 \pm 0.6 \mu \mathrm{g} / \mathrm{g}(24 \mathrm{~h})$ in liver and from $37.2 \pm 5.8 \mu \mathrm{g} / \mathrm{g}(30 \mathrm{~min})$ to $5.2 \pm 0.2 \mu \mathrm{g} / \mathrm{g}(24 \mathrm{~h})$ in kidney was observed [26]. In our study, free Les-3833 was cleared from these organs of mice in a similar way-from $1.02 \mu \mathrm{g} / \mathrm{g}(15 \mathrm{~min})$ to $0.42 \mu \mathrm{g} / \mathrm{g}(24 \mathrm{~h})$ in liver and from $0.4 \mu \mathrm{g} / \mathrm{g}$ $(15 \mathrm{~min})$ to $0.2 \mu \mathrm{g} / \mathrm{g}(24 \mathrm{~h})$ in kidney. These differences in clearance of doses of doxorubicin and Les-3833 in liver and kidney of treated rats and mice, respectively, are in agreement with the differing body masses of these animals-300-50 $\mathrm{g}$ in rats [26] and $26.3 \pm 2.1 \mathrm{~g}$ in mice (our study). In addition, the injected doses of these drugs were different $-6 \mathrm{mg} / \mathrm{kg}$ in rats [26] and $2.5 \mathrm{mg} / \mathrm{kg}$ in mice.

We found that Les-3833 was rapidly eliminated from brain and did not accumulate in the brain tissue of the treated mice (Figure 3). However, human glioma U251 cells and rat glioma C6 cells were much more sensitive to the toxic action of Les-3833 compared to tumor cells of other tissue origin (Table 2).

The liposomal encapsulation of doxorubicin was shown to affect its pharmacokinetics in blood plasma [26]. Its terminal half-life was $69.3 \mathrm{~h}$ compared to $17.3 \mathrm{~h}$ for free doxorubicin, and the area 
under the plasma concentration curve for liposomal doxorubicin was 40 fold higher than that for the free drug.

The distribution and binding characteristics of the applied drug can also affect its renal clearance [25,27]. Usually, a drug that is extensively bound to proteins has a long half-life, because its renal clearance is low and the urine flow rate is $1-2 \mathrm{~mL} / \mathrm{min}[19,27]$. Glomerular filtration and re-absorption are passive processes directly affected by the drug concentration in blood plasma. A drug that is not bound to plasma proteins and is excreted by filtration only shows a linear relationship between the rate of excretion and plasma drug concentration $[19,27]$.

The results of our study demonstrate that the distribution and elimination of Les-3833 takes place in the liver and kidney. A very small half-life for this compound in blood plasma and brain suggests that it is not accumulated in these tissues. Further pre-clinical pharmacokinetic studies are required for the novel synthetic heterocyclic 4-thiazolidinone, Les-3833, to evaluate its potential as an anticancer agent.

\section{Conclusions}

The tested 4-thiazolidinone derivative Les-3833 displayed prominent cytotoxicity effects on human (U251) and rat (C6) glioma cell lines with $\mathrm{LC}_{50}$ values of $0.84 \mu \mathrm{g} / \mathrm{mL}$ and $0.89 \mu \mathrm{g} / \mathrm{mL}$, respectively. The biodistribution parameters of Les-3833 showed that it was rapidly taken up by tissues from the bloodstream. Tracking the elimination pathways, Les-3833 was metabolized in the liver with a half-life of $24 \mathrm{~h}$ and excreted by the kidneys. In brain, Les-3833 was detected for a short time at a very low concentration.

Author Contributions: Conceptualization was done by L.K., R.L., R.S. and S.G.V.; Methodology and experimental works were done by L.K., A.L.; Data Analysis was done by L.K., R.L., R.S.; Writing, review and editing the paper were done by L.K., A.L., R.L. and S.G.V., Project administration and supervision were done by R.S. and S.V. All authors have read and agreed to the published version of the manuscript.

Funding: This work was supported by Cedars-Sinai Medical Center's International Research and Innovation in Medicine Program, and the Association for Regional Cooperation in the Fields of Health, Science and Technology (RECOOP HST Association) RECOOP Grant \#006 BMYS RG 2017-2019.

Acknowledgments: The authors would like to thank N. Finyuk and O. Klyuchivska (Institute of Cell Biology, NAS of Ukraine) for collaboration in conducting experiments with cultured mammalian cells.

Conflicts of Interest: The authors declare no conflict of interest.

\section{References}

1. Ali, R.; Mirza, Z.; Ashraf, G.M.; Kamal, M.A.; Ansari, S.A.; Damanhouri, G.A.; Abuzenadah, A.M.; Chaudhary, A.G.; Sheikh, I.A. New anticancer agents: Recent developments in tumor therapy. Anticancer Res. 2012, 32, 2999-3005. [PubMed]

2. Prager, G.; Unseld, M.; Waneck, F.; Mader, R.; Wrba, F.; Raderer, M.; Fuereder, T.; Staber, P.; Jäger, U.; Kieler, M.; et al. Results of the extended analysis for cancer treatment (EXACT) trial: A prospective translational study evaluating individualized treatment regimens in oncology. Oncotarget 2019, 10, $942-952$. [CrossRef] [PubMed]

3. Faqi, A.S. A Comprehensive Guide to Toxicology in Nonclinical Drug Development, 2nd ed.; Elsevier: London, UK, 2017; p. 657.

4. Kobayashi, H.; Carrasquillo, J.A.; Paik, C.H.; Waldmann, T.A.; Tagaya, Y. Differences of biodistribution, pharmacokinetics, and tumor targeting between interleukins 2 and 15. Cancer Res. 2000, 60, 3577-3583. [PubMed]

5. Xiao, W.; Luo, J.; Lam, K.; Henderson, P.; Jain, T.; Wriggs, J.; Tseng, H.P.; Henderson, P.T.; Cherry, S.R.; Rowland, D.; et al. Biodistribution and pharmacokinetics of a telodendrimer micellar paclitaxel nanoformulation in a mouse xenograft model of ovarian cancer. Int. J. Nanomed. 2012, 7, 1587-1597. [CrossRef] 
6. England, C.; Ehlerding, E.; Hernandez, R.; Rekoske, B.; Graves, S.; Sun, H.; Liu, G.; McNeel, D.G.; Barnhart, T.E.; Cai, W. Preclinical Pharmacokinetics and Biodistribution Studies of 89Zr-Labeled Pembrolizumab. J. Nucl. Med. 2016, 58, 162-168. [CrossRef]

7. Matzneller, P.; Kussmann, M.; Eberl, S.; Maier-Salamon, A.; Jäger, W.; Bauer, M.; Langer, O.; Zeitlinger, M.; Poeppl, W. Pharmacokinetics of the P-gp Inhibitor Tariquidar in Rats After Intravenous, Oral, and Intraperitoneal Administration. Eur. J. Drug. Metab. Ph. 2018, 43, 599-606. [CrossRef]

8. Wilsker, D.; Barrett, A.; Dull, A.; Lawrence, S.; Hollingshead, M.; Chen, A.; Kummar, S.; Parchment, R.E.; Doroshow, J.H.; Kinders, R.J. Evaluation of Pharmacodynamic Responses to Cancer Therapeutic Agents Using DNA Damage Markers. Clin. Cancer Res. 2019, 25, 3084-3095. [CrossRef]

9. Kobylinska, L.; Klyuchivska, O.; Grytsyna, I.; Finiuk, N.; Panchuk, R.; Starykovych, M.; Lehka, L.; Lesyk, R.B.; Zimenkovsky, B.S.; Stoika, R.S. Differential pro-apoptotic effects of synthetic 4-thiazolidinone derivative Les-3288, doxorubicin and temozolomide in human glioma U251 cells. Croat. Med. J. 2017, 58, 150-159. [CrossRef]

10. Kobylinska, L.; Klyuchivska, O.; Lesyk, R.; Stoika, R. Targeting of the pro-oxidant-antioxidant balance in vitro and in vivo by 4 -thiazolidinone-based chemotherapeutics with anticancer potential. Ukr. Biochem. J. 2019, 91, 7-17. [CrossRef]

11. Kobylinska, L.; Skorohyd, N.; Klyuchivska, O.; Mitina, N.; Zaichenko, A.; Lesyk, R.; Zimenkovsky, B.S.; Stoika, R.S. Increased antitumor efficiency and reduced negative side effects in laboratory mice of 4-thiazolidinone derivatives in complexes with PEG-containing polymeric nanocarrier. Biopolym. Cell. 2018, 34, 313-328. [CrossRef]

12. Havrylyuk, D.; Zimenkovsky, B.; Vasylenko, O.; Day, C.; Smee, D.; Grellier, P.; Lesyk, R. Synthesis and biological activity evaluation of 5-pyrazoline substituted 4-thiazolidinones. Eur. J. Med. Chem. 2013, 66, 228-237. [CrossRef] [PubMed]

13. Havrylyuk, D.; Kovach, N.; Zimenkovsky, B.; Vasylenko, O.; Lesyk, R. Synthesis and Anticancer Activity of Isatin-Based Pyrazolines and Thiazolidines Conjugates. Arch. Pharm. 2011, 344, 514-522. [CrossRef] [PubMed]

14. Cutshall, N.; O'Day, C.; Prezhdo, M. Rhodanine derivatives as inhibitors of JSP-1. Bioorg. Med. Chem. Lett. 2005, 15, 3374-3379. [CrossRef] [PubMed]

15. Carter, P.; Scherle, P.; Muckelbauer, J.; Voss, M.; Liu, R.; Thompson, L.; Tebben, A.J.; Solomon, K.A.; Lo, Y.C.; Li, Z.; et al. Photochemically enhanced binding of small molecules to the tumor necrosis factor receptor-1 inhibits the binding of TNF- $\alpha$. Proc. Natl. Acad. Sci. USA 2001, 98, 11879-11884. [CrossRef] [PubMed]

16. Manna, F.; Chimenti, F.; Fioravanti, R.; Bolasco, A.; Secci, D.; Chimenti, P.; Ferlini, C.; Scambia, G. Synthesis of some pyrazole derivatives and preliminary investigation of their affinity binding to P-glycoprotein. Bioorg. Med. Chem. Lett. 2005, 15, 4632-4635. [CrossRef]

17. Kobylinska, L.; Ivasechko, I.; Skorokhyd, N.; Panchuk, R.; Riabtseva, A.; Mitina, N.; Zaichenko, A.; Lesyk, R.; Zimenkovsky, B.; Stoika, R.; et al. Enhanced Proapoptotic Effects of Water Dispersed Complexes of 4-Thiazolidinone-Based Chemotherapeutics with a PEG-Containing Polymeric Nanocarrier. Nanoscale Res. Lett. 2019, 14. [CrossRef]

18. Havrylyuk, D.; Zimenkovsky, B.; Vasylenko, O.; Gzella, A.; Lesyk, R. Synthesis of New 4-Thiazolidinone-, Pyrazoline-, and Isatin-Based Conjugates with Promising Antitumor Activity. J. Med. Chem. 2012, 55, 8630-8641. [CrossRef]

19. Marenberg, B. FDA Issues Final Rule on Patent Listing Requirements and 30-Month Stays of Approval Following Submission of Abbreviated New Drug Applications. Biotechnol. Law Rep. 2004, 23, 48-51. [CrossRef]

20. Kobylinska, L.; Boiko, N.; Panchuk, R.; Grytsyna, I.; Klyuchivska, O.; Biletska, L.; Lesyk, R.B.; Zimenkovsky, B.S.; Stoika, R.S. Putative anticancer potential of novel 4-thiazolidinone derivatives: Cytotoxicity toward rat C6 glioma in vitro and correlation of general toxicity with the balance of free radical oxidation in rats. Croat. Med. J. 2016, 57, 151-163. [CrossRef]

21. Kobylinska, L.; Havrylyuk, D.Y.; Ryabtseva, A.O.; Mitina, N.E.; Zaichenko, O.S.; Zimenkovsky, B.S.; Stoika, R.S. Study of rat blood serum biochemical indicators of cardiotoxic action of novel antitumor 4-thiazolidinone derivatives and doxorubicin in complexes with polyethylenglycol-containing polymeric carrier in the rat blood serum. Ukr. Biochem. J. 2014, 86, 84-95. [CrossRef] 
22. Chumak, V.; Panchuk, R.; Manko, N.; Havrylyuk, D.; Lesyk, R.; Kobylinska, L.; Zimenkovsky, B.; Stoika, R. Comparative study of the cytotoxic properties of isatin-containing derivatives of 4-thiazolidinone with different structure toward human tumor cells in vitro. Stud Biol. 2014, 8, 29-42. [CrossRef]

23. Kobylinska, L.; Havrylyuk, D.Y.; Ryabtseva, A.O.; Mitina, N.E.; Zaichenko, O.S.; Lesyk, R.B.; Zimenkovsky, B.S.; Stoika, R.S. Biochemical indicators of hepatotoxicity in blood serum of rats under the effect of novel 4-thiazolidinone derivatives and doxorubicin and their complexes with polyethyleneglycol-containing nanoscale polymeric carrier. Ukr. Biochem. J. 2015, 87, 122-132. [CrossRef]

24. Kobylinska, L.; Havrylyuk, D.; Mitina, N.; Zichenko, A.S.; Lesyk, R.B.; Zimenkovsky, B.S.; Stoika, R.S. Biochemical indicators of nephrotoxicity in blood serum of rats treated with novel 4-thiazolidinone derivatives or their complexes with polyethylene glycol-containing nanoscale polymeric carrier. Ukr. Biochem. J. 2016, 88, 51-60. [CrossRef]

25. Rollerova, E.; Tulinska, J.; Liskova, A.; Kuricova, M.; Kovriznych, J.; Mlynarcikova, A.; Kiss, A.; Scsukova, S. Titanium dioxide nanoparticles: Some aspects of toxicity/focus on the development. Endocr. Regul. 2015, 49, 97-112. [CrossRef] [PubMed]

26. Rahman, A.; Carmichael, D.; Harris, M.; Roh, J.K. Comparative pharmacokinetics of free doxorubicin and doxorubicin entrapped in cardiolipin liposomes. Cancer Res. 1986, 46, 2295-2299. [PubMed]

27. Beechinor, R.; Gonzalez, D. Book Review: Introduction to Drug Disposition and Pharmacokinetics. Clin. Pharmacol. Ther. 2017, 102, 893. [CrossRef]

(C) 2020 by the authors. Licensee MDPI, Basel, Switzerland. This article is an open access article distributed under the terms and conditions of the Creative Commons Attribution (CC BY) license (http://creativecommons.org/licenses/by/4.0/). 